\title{
Hepatoprotective effect of Phytosome Curcumin against paracetamol-induced liver toxicity in mice
}

\author{
Bui Thanh Tung*, Nguyen Thanh Hai, Phan Ke Son
}

School of Medicine and Pharmacy, Vietnam National University, Hanoi, Vietnam

\begin{abstract}
Curcuma longa, which contains curcumin as a major constituent, has been shown many pharmacological effects, but it is limited using in clinical due to low bioavailability. In this study, we developed a phytosome curcumin formulation and evaluated the hepatoprotective effect of phytosome curcumin on paracetamol induced liver damage in mice. Phytosome curcumin (equivalent to curcumin 100 and $200 \mathrm{mg} / \mathrm{kg}$ body weight) and curcumin ( $200 \mathrm{mg} / \mathrm{kg}$ body weight) were given by gastrically and toxicity was induced by paracetamol $(500 \mathrm{mg} / \mathrm{kg})$ during 7 days. On the final day animals were sacrificed and liver function markers (ALT, AST), hepatic antioxidants (SOD, CAT and GPx) and lipid peroxidation in liver homogenate were estimated. Our data showed that phytosome has stronger hepatoprotective effect compared to curcumin-free. Administration of phytosome curcumin effectively suppressed paracetamol-induced liver injury evidenced by a reduction of lipid peroxidation level, and elevated enzymatic antioxidant activities of superoxide dismutase, catalase, glutathione peroxidase in mice liver tissue. Our study suggests that phytosome curcumin has strong antioxidant activity and potential hepatoprotective effects.
\end{abstract}

Uniterms: Curcumin/effects. Curcumin/antioxidant activity. Curcuma longa. Phytosome. Hepatoprotective.

\section{INTRODUCTION}

Curcumin is a polyphenol extracted from the rhizomes of Curcuma longa. It has a yellow color, and traditional used in many foods. Curcumin has been shown many beneficial biological activities including antioxidant, anti-inflammatory, anticoagulant, antitumor and hepatoprotective activities (Anand et al., 2008) . However, curcumin has a limited to use as a drug to treat the disease because of its poor solubility in water and its low oral bioavailability (Prasad, Tyagi, Aggarwal, 2014; Siviero et al., 2015). Therefore, it is needed to develop a new preparation of curcumin, to enhance the absorption and pharmacological activity.

Some intents to improve the bioavailability of curcumin, such as the using of nanoparticles, liposomes, structural analogues and phospholipid complexes (Gupta, Patchva, Aggarwal, 2013). Phytosome is a

\footnotetext{
*Correspondence: B. T. Tung. School of Medicine and Pharmacy. Vietnam National University. Hanoi, Office 506, Building Y1, 144, Xuan Thuy, Cau Giay, Ha Noi, Vietnam. E-mail: tungasia82@yahoo.es
}

technology, which incorporate natural product compound or extract into phospholipids to produce lipid compatible molecular complex and then increase their absorption and bioavailability. Marczylo have prepared a formulation of curcumin with phosphatidylcholine (phytosome curcumin) to increase its oral bioavailability. The author showed that the maximum plasma concentration and area under the plasma concentration time curve values for phytosome curcumin after administration were fivefold higher than the equivalent values seen after curcumin free in rats plasma (Marczylo et al., 2007). In other study, the bioavailability of phytosome curcumin was investigated in human clincal trial. Phytosome curcumin showed the total curcuminoid absorption was 29-fold higher than for its corresponding curcuminoid free. Interestingly, the main plasma curcuminoid after administration of phytosome curcumin was demethoxycurcumin, but not curcumin (Cuomo et al., 2011).

Many study has demonstrated that the main causes of the damage liver is linked to reactive oxygen species (ROS) (Jaeschke, Ramachandran 2011). ROS can attack to polyunsaturated fatty acids in cellular membranes, 
the proteins groups and DNA bases. The cells had to develop efficiency defense systems to prevent damages with their own antioxidant enzyme system. Paracetamol has been widely used in model of hepatotoxicity in mice (McGill et al., 2012). The biochemical changed with paracetamol toxicity seems to be a significantly increasing in serum alanine aminotransferase (ALT) and asparatate aminotransferase (AST) levels and decreasing the antioxidant enzyme endogenous in liver (Hinson, Roberts, James, 2010).

In our recent publication, we have prepared saponinphospholipids complex to increase the pharmacological effect of saponin having poor oral absorption (Kim et $a l ., 2016)$. Continue studying to improve bioavailability of natural product, in this paper we aimed to prepare phytosome curcumin and determine its physicochemical characteristics and evaluate its hepatoprotective effect in paracetamol-induced mice, compare with curcumin free.

\section{MATERIAL AND METHODS}

\section{Preparation of phytosome curcumin}

Phytosome curcumin was prepared by reaction between curcumin and phosphatidylcholine at different molar ratios: $1: 1 ; 1: 2 ; 1: 4$, each ratio was repeated three times. Weigh exactly $2.04 \mathrm{~g}$ curcumin powder and 4.35 g phosphatidylcholine and put to $100 \mathrm{~mL}$ round bottom flask, then added $30 \mathrm{~mL}$ of dichloromethane. The mixture was refluxed at $40{ }^{\circ} \mathrm{C}$ with magnetic stirring for 2 hours. Then solution was evaporated to remove dichloromethane and added $50 \mathrm{~mL} n$-hexane. The obtained complex was precipitated, filtered and dried under vacuum to obtain the phytosome complex.

\section{Morphology and structure of phytosome curcumin}

Using the method of negative staining transmission electron microscopy (TEM) scanning electron microscope (SEM).

\section{Determination of curcumin content in the phytosome curcumin}

Standard curve of curcumin concentration

Approximately $100 \mathrm{mg}$ curcumin powder was dissolved in methanol in $25 \mathrm{~mL}$ volumetric flask (4 mg/ $\mathrm{mL})$. This solution was diluted $1000-10000 \mathrm{x}(4 \mu \mathrm{g} / \mathrm{mL}-$ $0.4 \mu \mathrm{g} / \mathrm{mL}$ ) and filtered through membrane $0.45 \mu \mathrm{m}$ and prepared a standard curve of curcumin by using a HPLC method. The mobile phase used was water and acetonitrile gradient as following:

Mobil phase

Using water and acetonitrile gradient as following:

\begin{tabular}{|l|l|l|}
\hline Time (min) & \% water & \% acetonitrile \\
\hline 0.00 & 70.0 & 30.0 \\
\hline 20.00 & 50.0 & 50.0 \\
\hline 23.00 & 70.0 & 30.0 \\
\hline
\end{tabular}

Detector: UV -VIS, $425 \mathrm{~nm}$.

Flow rate: $1,0 \mathrm{~mL} / \mathrm{min}$

Injection volume: $10 \mu \mathrm{L}$

Column: Agilent ZORBAX Eclipse Plus 95Å C18, 4.6 x $100 \mathrm{~mm}$, diameter $3,5 \mu \mathrm{m}$.

Determination of curcumin content in the complex

Approximately $50 \mathrm{mg}$ of phytosome was dissolved in methanol in $25 \mathrm{mLvolumetric} \mathrm{flask}(2 \mathrm{mg} / \mathrm{mL})$. These solutions were diluted 1000x $(2 \mu \mathrm{g} / \mathrm{mL})$. This solution was filtered through membrane $0.45 \mu \mathrm{m}$ and percentage of curcumin was determined by using the HPLC method as described above.

\section{Yield of process}

Weight exactly amount of phytosome, curcumin, disperse in water with 1:100 (w/v). Centrifugate at 8000 rpm during $30 \mathrm{~min}$. Filter, take the solid and disolve in methanol. Curcumin's was concentration was determined by using a HPLC method.

Yield of process was calculated by:

$$
\mathrm{Y}(\%)=\frac{m_{\text {cur total }}-m_{\text {cur free }}}{m_{\text {cur total }}} \times 100 \%
$$

\section{Infrared (IR) spectroscopy}

Infrared spectrum of curcumin, phosphatidylcholine and phytosome was measured by Fourier transform infrared spectroscopy (FTIR).

\section{Differential scanning calorimetry (DSC)}

The samples were sealed in the aluminum crimp cell and heated at the speed of $10{ }^{\circ} \mathrm{C} / \mathrm{min}$ from 0 to $800^{\circ} \mathrm{C}$ in nitrogen atmosphere $(60 \mathrm{~mL} / \mathrm{min})$. The peak transition onset temperature of the obtained complexes were determined and compared with the help of a Mettler DSC 30S (Mettler Toledo, US) (Shyam, Kumar, 2012). 


\section{${ }^{1} \mathrm{H}-\mathrm{NMR}$ Spectroscopy}

${ }^{1} \mathrm{H}-\mathrm{NMR}\left(500 \mathrm{MH}_{\mathrm{Z}} \mathrm{CDCl}_{3}, \delta\right.$ in ppm) spectroscopy of curcumin, phosphatidylcholine, and phytosome curcumin was carried out by using Brucker Advance DRX-500, BruckerBioSciences Corporation, Billerica, MA, USA) at $500 \mathrm{MHz}$ (Maiti et al., 2007).

\section{Particle Size and Zeta Potential analysis}

The particle size and zeta potential of phytosome curcumin were determined at $25^{\circ} \mathrm{C}$ using photon correlation spectroscopy (ZetaSizer Nano-ZS90, Malvern, UK). The analysis consisted of $100 \mathrm{mg}$ of phytosome curcumin powders were dispersed in about $15 \mathrm{~mL}$ of double-distilled water before analysis.

\section{Solubility studies}

Solubility of curcumin, phytosome curcumin and physical mixture of curcumin and phosphatidylcholine were evaluated by adding excess of the samples to $5 \mathrm{~mL}$ of water in glass container at room temperature. The liquids were shaken for $24 \mathrm{~h}$ and centrifuged at $5000 \mathrm{rpm}$ for $10 \mathrm{~min}$. The supernatant was filtered by membrane $0,45 \mu \mathrm{m}$. Dilute $1 \mathrm{~mL}$ with methanol to $10 \mathrm{~mL}$ and their curcumin's concentration were measured by HPLC method (Maiti et al., 2007).

\section{Animals}

Fifty $(25-30 \mathrm{~g})$ Swiss mice were used to study the hepatoprotective activity of the phytosome curcumin. The animals were kept at $27 \pm 2{ }^{\circ} \mathrm{C}$, relative humidity $44-56 \%$ and light and dark cycles of $12 \mathrm{~h}$, for 5 days before and during the experiments. Animals were provided with standard diet and water ad libitum. Mice were randomly divided into five groups, each group consisting of ten mice.

Group I received a single daily dose of $1 \mathrm{~mL} / \mathrm{kg}$ of saline orally (NC group).

Group II was given a single daily dosing of paracetamol (500 mg/kg) orally (PAR group).

Group III was given orally a single daily dose of both 500 $\mathrm{mg} / \mathrm{kg}$ paracetamol and $200 \mathrm{mg} / \mathrm{kg}$ of Curcumin (CUR group).

Group IV was given orally a single daily dose of both 500 $\mathrm{mg} / \mathrm{kg}$ paracetamol and amount phytosome curcumin equivalent to curcumin $100 \mathrm{mg} / \mathrm{kg}$ b.w (Phyt 100 group). Group V was given orally a single daily dose of both 500 $\mathrm{mg} / \mathrm{kg}$ paracetamol and amount phytosome curcumin equivalent to curcumin $200 \mathrm{mg} / \mathrm{kg}$ b.w (Phyt 200 group).
Phytosome curcumin was administered three hours after the administration of paracetamol. The treatments were continued for seven days and on the final day of the experiment blood were taken from carotid artery of all animals and then mice were sacrificed by cervical dislocation. All liver tissues were dissected, washed in $0.9 \% \mathrm{NaCl}$ and frozen rapidly at $-80{ }^{\circ} \mathrm{C}$. Frozen tissues defrosted, weighted and homogenized in ice-cold lysis buffer, containing $50 \mathrm{mM}$ Tris- $\mathrm{HCl}$ ( $\mathrm{pH} 7.5), 8 \mathrm{mM}$ $\mathrm{MgCl}_{2}, 5 \mathrm{mM}$ ethylene glycol bis (2-aminoethyl ether)$\mathrm{N}, \mathrm{N}, \mathrm{N}$ ',N'-tetraacetic acid (EGTA), 0.5 mM EDTA, 0.01 $\mathrm{mg} / \mathrm{mL}$ leupeptin, $0.01 \mathrm{mg} / \mathrm{mL}$ pepstatin, $0.01 \mathrm{mg} / \mathrm{mL}$ aprotinin, $1 \mathrm{mM}$ phenylmethylsulfonyl fluoride (PMSF) and $250 \mathrm{mM} \mathrm{NaCl}$. Homogenates were then centrifuged at $12000 \times \mathrm{g}$ for $10 \mathrm{~min}$ at $4{ }^{\circ} \mathrm{C}$. The supernatants was collected and stored until use at $-80{ }^{\circ} \mathrm{C}$. Protein concentration was determined by Bradford's method (Noble, Bailey, 2009).

\section{Hepatotoxicity}

Serum levels of ALT and AST as markers of hepatic function were measured by using a ALT Activity Assay Kit and AST Activity Assay Kit (Sigma-Aldrich, Singapore) according to the manufacturer's instructions.

\section{Lipid peroxidation assay}

Lipid peroxidation assay was performed by determining the reaction of malonaldehyde with two molecules of 1-methyl-2-phenylindole at $45^{\circ} \mathrm{C}$ as described previously (Thanh et al., 2016; Thanh et al., 2015). The reaction mixture consisted of $0.64 \mathrm{~mL}$ of $10.3 \mathrm{mM} 1$-methyl-2-phenylindole, $0.2 \mathrm{~mL}$ of sample and $10 \mu \mathrm{L}$ of $2 \mu \mathrm{g} / \mathrm{mL}$ butylated hydroxytoluene. After vigorously mixing, $0.15 \mathrm{~mL}$ of $37 \% \mathrm{v} / \mathrm{v} \mathrm{HCl}$ was added. The mixture was incubated at $45^{\circ} \mathrm{C}$ for $45 \mathrm{~min}$ and centrifuged at $10,000 \mathrm{~g}$ for $10 \mathrm{~min}$. Cleared supernatant absorbance was recorded at $586 \mathrm{~nm}$. A calibration curve prepared from 1,1,3,3- tetramethoxypropane (Sigma-Aldrich, Singapore) was used for calculation. Peroxidized lipids were expressed as nmol MDA equivalents/mg protein.

\section{Superoxide dismutase (SOD) activity determination}

SOD activity was determined as described previously (Thanh et al., 2015). This method is based on the capacity of SOD to inhibit the autoxidation of pyrogallol. Each assay was measured in triplicate. 


\section{Ratio \\ Curcumin: Phospholipids}

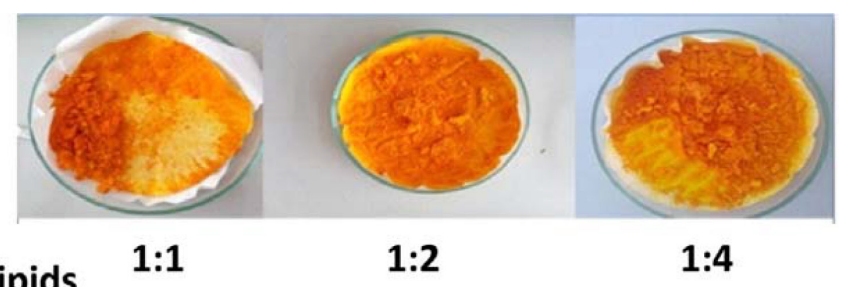

FIGURE 1 - Physical properties of curcumin phytosome at different ratios.

\section{Catalase (CAT) activity determination}

CAT activity was measured in triplicate by monitoring the disappearance of $\mathrm{H}_{2} \mathrm{O}_{2}$ at $240 \mathrm{~nm}$ as described previously (Thanh et al., 2015). Each assay was measured in triplicate.

\section{Glutathione peroxidase (GPx) activity determination}

Glutathione peroxidase (GPx) activity was measured with a coupled enzyme assay described previously (Thanh et al., 2015). Each assay was measured in triplicate.

\section{Statistical analysis}

All data are expressed as the mean \pm standard deviation (SD). One-way analysis of variance (ANOVA) was used to determine significance among groups. Statistical significance was set at $\mathrm{p}<0.05$.

\section{RESULTS}

\section{Physical properties of phytosome curcumin}

The resultant complexes after dried under vacuum were kept in petri disk (Figure 1). All phytosomes have orange-yellow powders, but the phytosome with the ratio curcumin and phosphatidylcholine $1: 1$ were softer and smoother while phytosome with ratio curcumin and phosphatidylcholine 1:2 and 1:4 seemed to be more sticky and clammy. That may be explained by the more presence of phosphatidylcholine in the samples.

\section{Morphology of phytosome curcumin}

SEM and TEM images demonstrate the formation of particles. As shown in Figure 2 (A, B) the particles observed under SEM showed spherical-shaped particles. The TEM showed that particles phytosome curcumin are uniforms and homogeneous.
A- SEM of phytosome curcumin

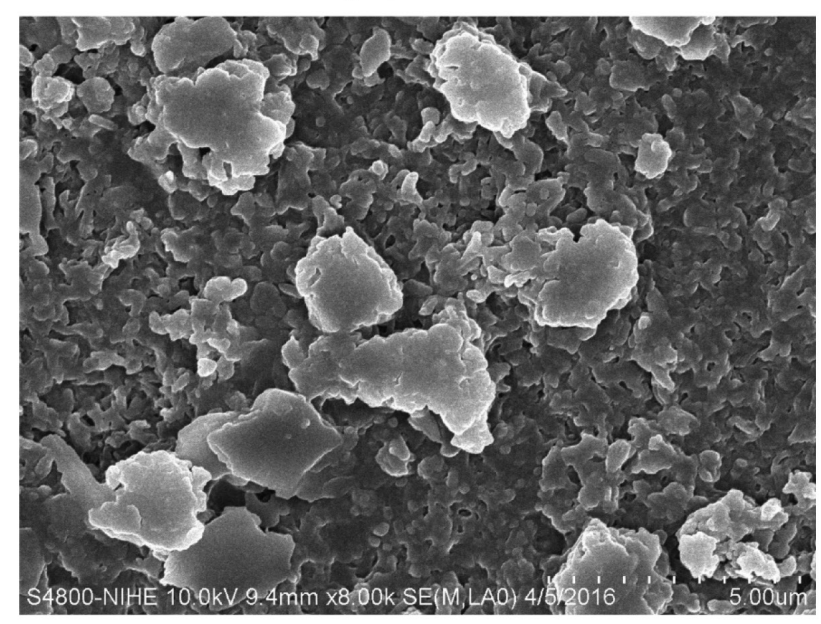

B- TEM of phytosome curcumin

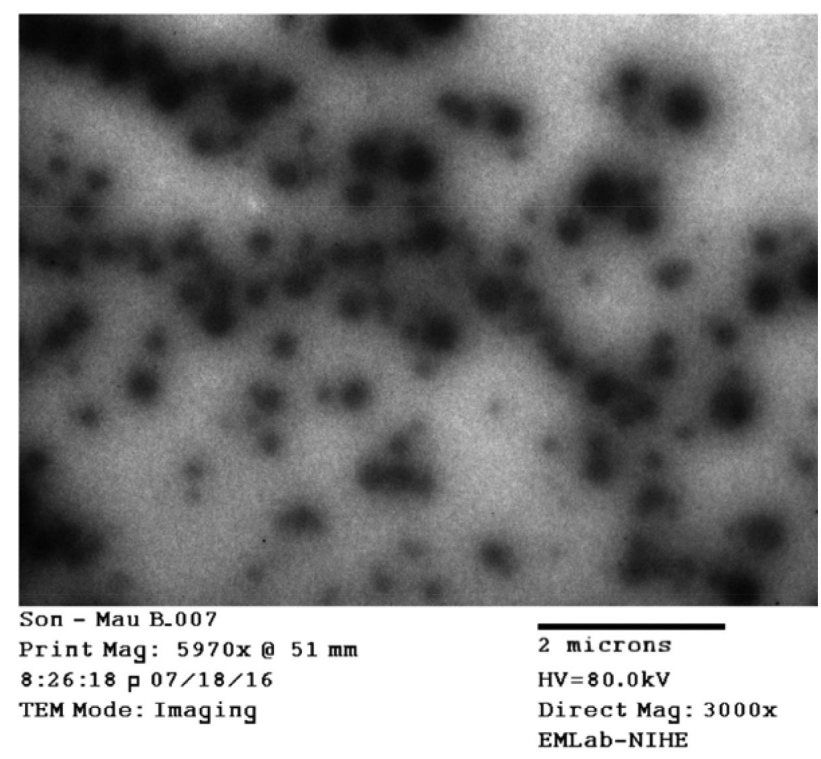

FIGURE 2 - Phytosome curcumin was taken by SEM (A) and TEM (B) of phytosome curcumin with curcumin: phosphatidylcholine ratio is $1: 1$.

\section{Yield of phytosome preparation process}

Yield of phytosome preparation process was presented in Table I. 
TABLE I - Total yield of phytosome preparation process

\begin{tabular}{cc}
\hline $\begin{array}{c}\text { Curcumin: } \\
\text { phosphatidylcholine ratio }\end{array}$ & Total yield (w/w,\%) \\
\hline $1: 1$ & $87.74 \pm 1.73$ \\
\hline $1: 2$ & $91.61 \pm 2.24$ \\
\hline $1: 4$ & $94.64 \pm 2.64$ \\
\hline
\end{tabular}

Table I showed that total yield of the preparation process increased following the rise of phosphatidylcholine amount added in the complexes. With the curcumin: phosphatidylcholine ratio is $1: 2$ and $1: 4$, the yield can be about $94 \%$. However, this yield is only about $81 \%$ when the ratio is $1: 1$. This can be explained by adding the large amount of phosphatidylcholine, the ability of interaction between curcumin and phosphatidylcholine was higher, lead to form more phytosome curcumin complex.

\section{Determination of curcumin content in the complex}

The curcumin content in the phytosome was shown in Table II.
The curcumin content in the complex was determined by HPLC method. A HPLC chromatographical of phytosome curcumin with curcumin: phosphatidylcholine ratio (mol:mol) 1:1 is shown in Figure 3. The percentages of curcumin in the phytosome in sample at ratio 1:1 are higher than curcumin in other ratio. The amount of curcumin reached $25.64 \%$ in the complexes with curcumin: phospholipis ratio 1:1. However, curcumin content reached $12.61 \%$ and $8.97 \%$ in the complexes with $1: 2$ and $1: 3$ ratios, respectively.

\section{Particles size and zeta potential of phytosome curcumin}

The distribution of the size of phytosome curcumin was shown in Figure 4. The average size of phytosome curcumin was $131.8 \mathrm{~nm}$ and PDI was 0.191 . The zeta potential of PEG-CUR was $-44.5 \mathrm{mV}$. One important parameter of nanoparticles is the polydispersity index (PDI), which is measured the particle size distribution. If PDI is smaller than 0.1 , the particles are typically referred to as "monodisperse" (Moreira, Gaspar, Allen, 2001; Pereira-Lachataignerais et al., 2006; Pham et al., 2015). Our particles of phytosome curcumin are shown to be

TABLE II - Curcumin content in the phytosome

\begin{tabular}{lccc}
\hline Sample (curcumin:phosphatidylcholine ratio) & $1: 1$ & $1: 2$ & $1: 4$ \\
\hline Curcumin content (\%) & $25.64 \pm 2.01$ & $12.61 \pm 1.76$ & $8.97 \pm 1.25$ \\
\hline
\end{tabular}

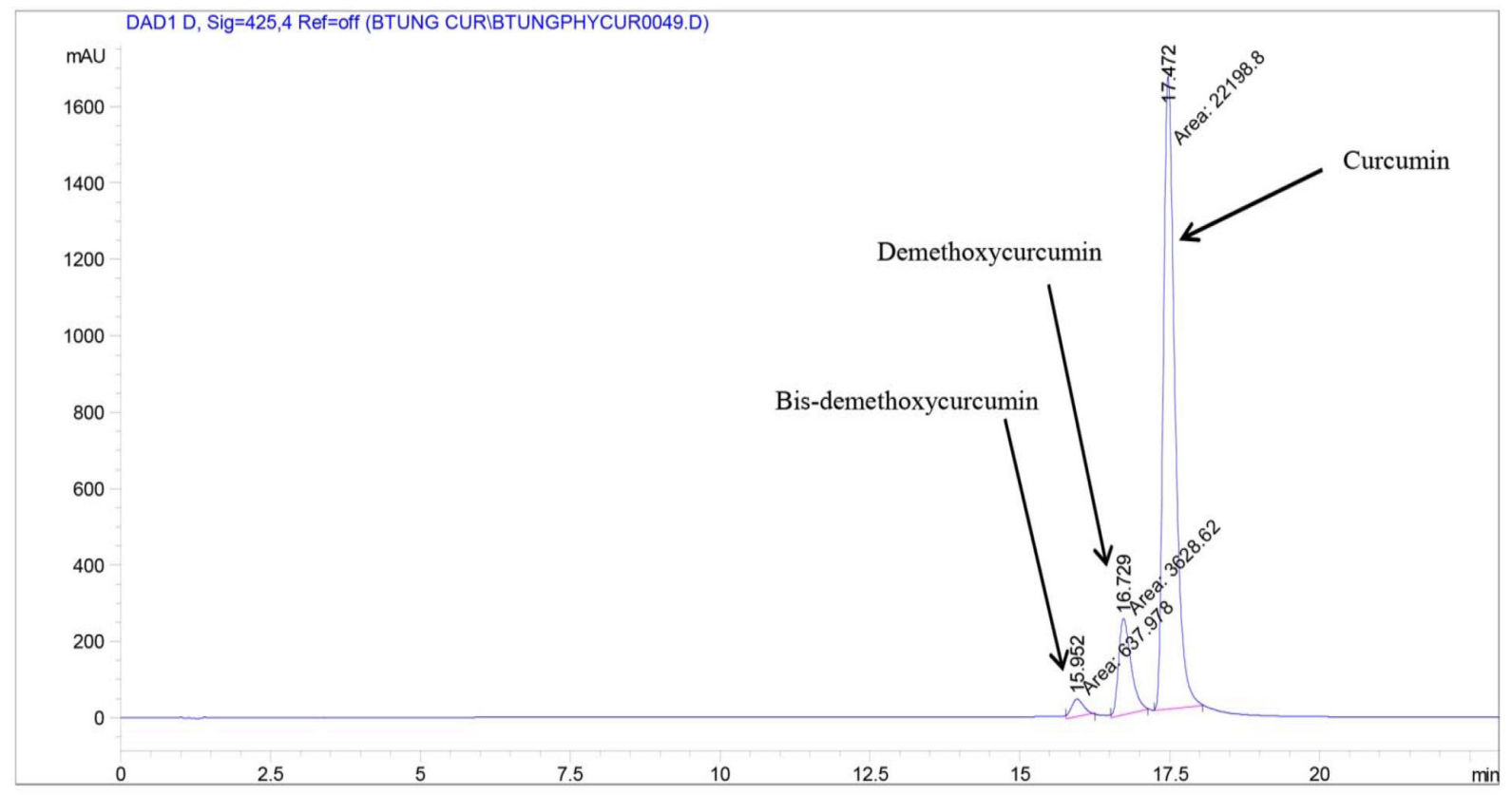

FIGURE 3 - Representative chromatograms HPLC chromatographical of Phytosome curcumin with curcumin: phosphatidylcholine ratio (mol:mol) is $1: 1$. 
quite uniforms with PDI was 0.191 and have an average size of $131.8 \mathrm{~nm}$.

The index used to evaluate the stability of particle system is zeta potential value. If the particles possess the absolute value of zeta potential greater than $30 \mathrm{mV}$, then the particle system is highly stable and able to prevent the aggregation of particles. If zeta potential values are in the range of $20-30 \mathrm{mV}$, the particle system is relatively stable (Eloy et al., 2014; Pham et al., 2015). Our PEG-CUR has zeta potential values of $-44.5 \mathrm{mV}$, it can be considered they are a relatively stable system.

\section{Infrared (IR) spectroscopy}

IR spectra of curcumin, phosphatidylcholine and phytosome are shown in Figure 5. The IR spectra of curcumin showed two peaks at $\lambda 1625.99$ and $1600.92 \mathrm{~cm}^{-1}$ which represent for $\mathrm{C}=\mathrm{C}$ and $\mathrm{C}=\mathrm{O}$ bonds, but disappear

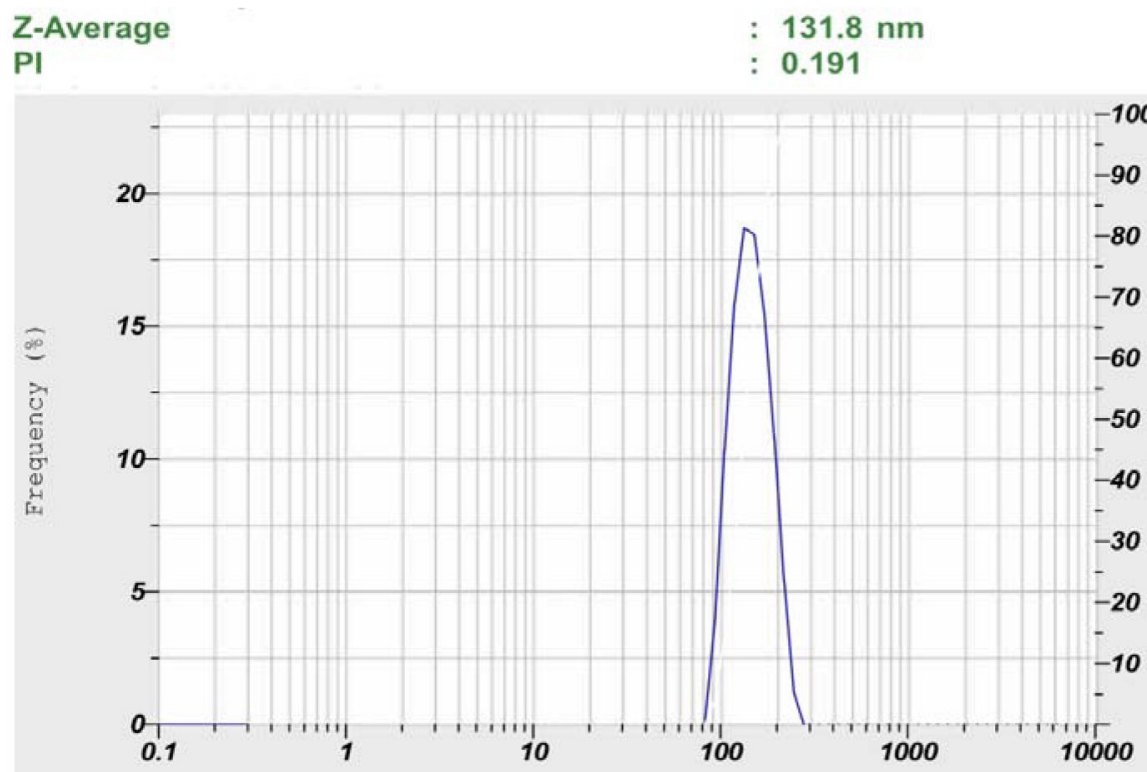

(A)

Diameter $(\mathrm{nm})$

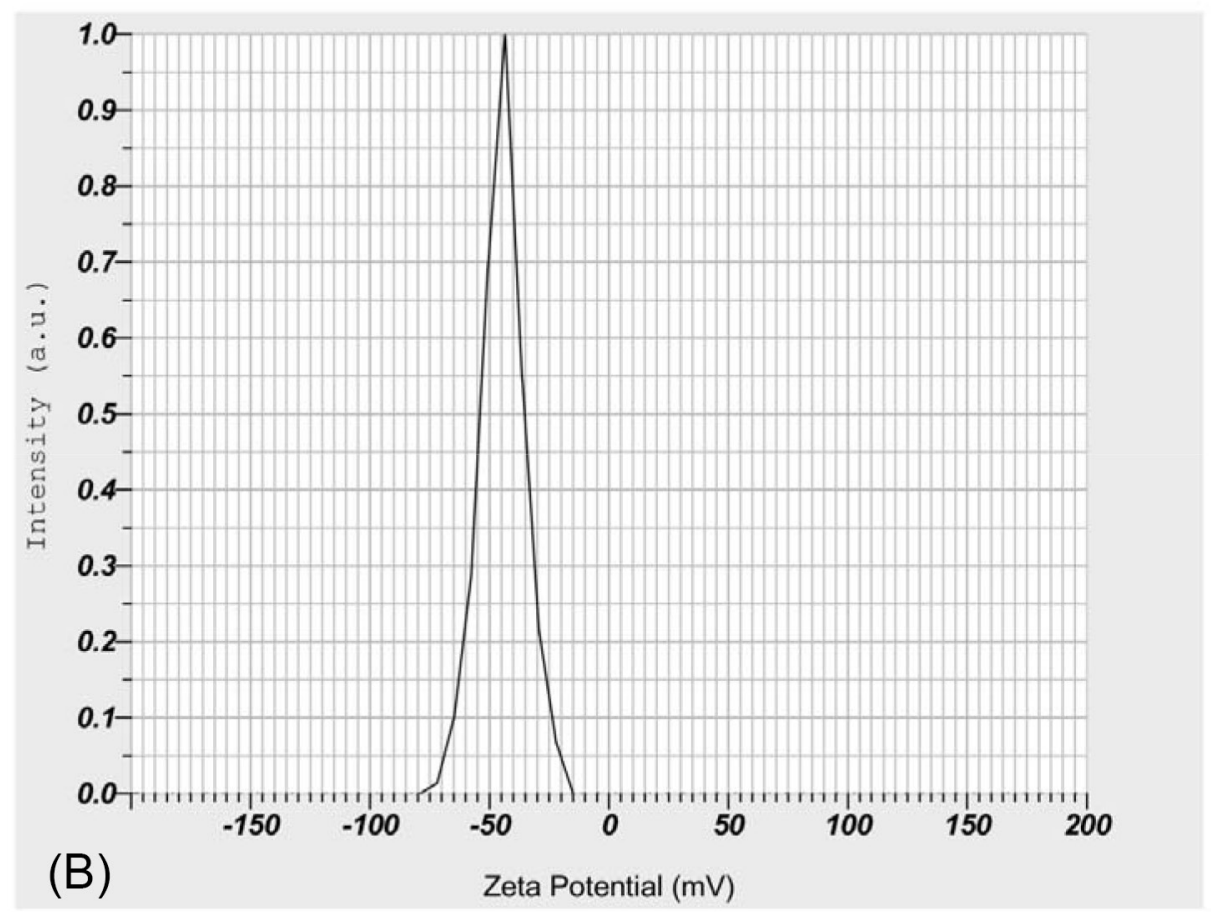

FIGURE 4 - Distribution of PEG-CUR size (A) and zeta potential (B). 


\section{A. Curcumin}

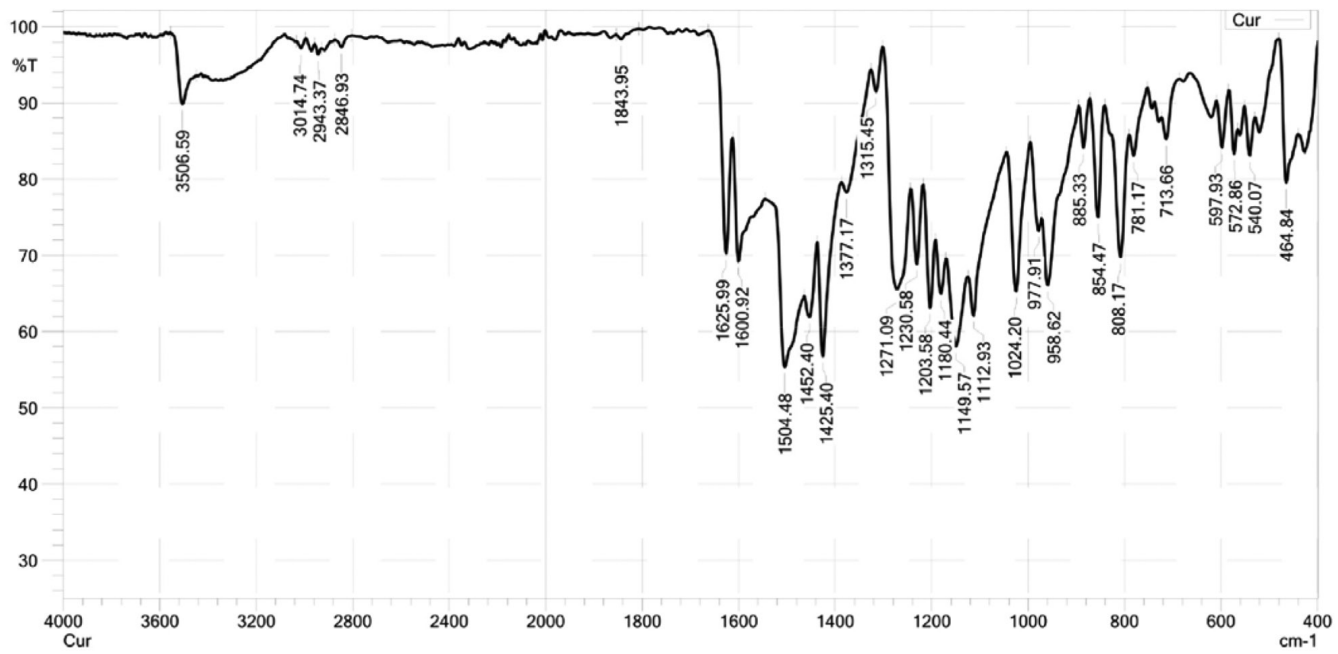

B. Phosphatidylcholine

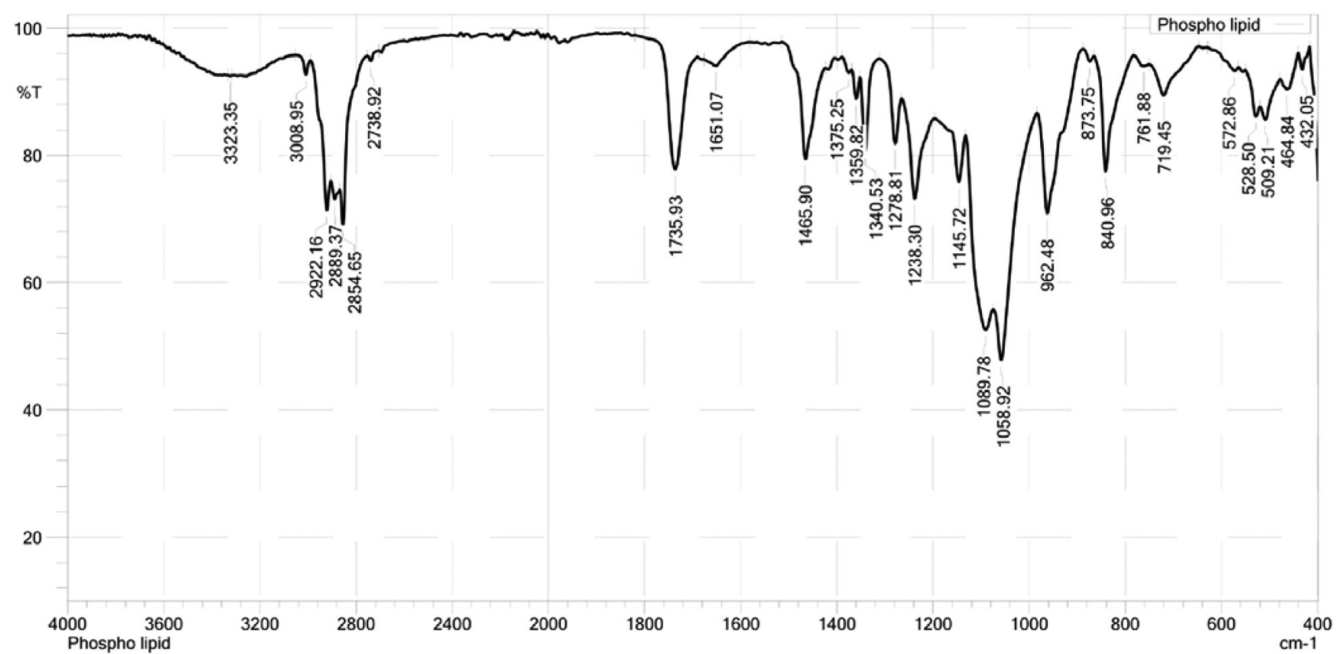

\section{Phytosome curcumin}

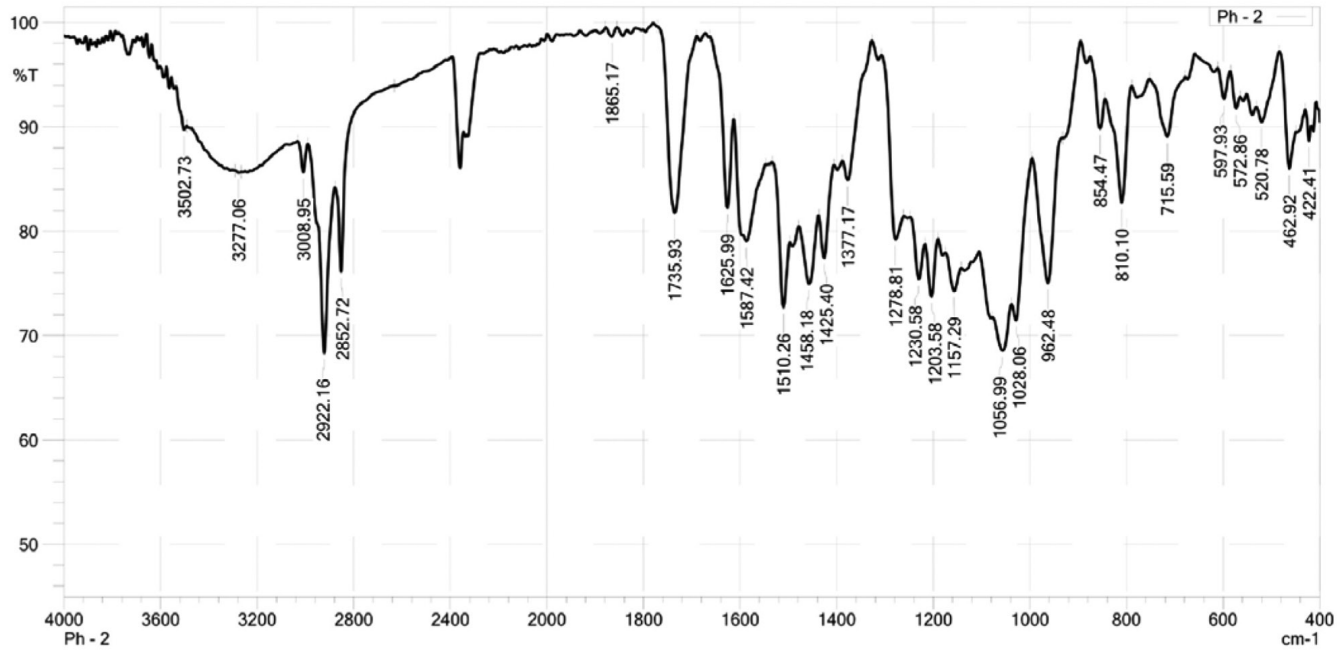

FIGURE 5 - Infrared spectrum of curcumin, phosphatidylcholine and phytosome curcumin. 
in phytosome's IR spectra. The peak at $\lambda 1734.01 \mathrm{~cm}^{-1}$ presents in both IR spectra of phosphatidylcholine and phytosome curcumin. Moreover, the peak at $\lambda 3506.59$ $\mathrm{cm}^{-1}$ of $\mathrm{OH}$ group in curcumin structure and two peaks at $\lambda 2916.37$ and $2848.86 \mathrm{~cm}^{-1}$ in phosphatidylcholine structure are also presented in phytosome curcumin's IR spectrum. Interestingly, there is a new peak at $\lambda 3745.76$ $\mathrm{cm}^{-1}$ and some fluctuations appearing from 3200 to $4000 \mathrm{~cm}^{-1}$ in phytosome's IR spectrum. This confirms the presence of hydrogen bonds between curcumin and phosphatidylcholine. Therefore, it is suggested that in the phytosome, curcumin bounds to the polar head of phosphatidylcholine while the non-polar part of phosphatidylcholine still are freely and envelops the polar part containing curcumin molecules.

\section{Differential scanning calorimetry (DSC)}

Figure 6 reveals the DSC thermographs of curcumin (A), phosphatidylcholine (B) and phytosome curcumin (C). DSC spectrum of curcumin showed the onset temperature of the melting processes is $155.8172^{\circ} \mathrm{C}$ corresponds to peak at $185.0430{ }^{\circ} \mathrm{C}$ which is the curcumin's melting temperature. Phosphatidylcholine has a melting peak at $149.5276{ }^{\circ} \mathrm{C}$ corresponds to the temperature when hydrocarbon tails of phosphatidylcholine transform from gel state to liquid crystalline. DSC of phytosome curcumin do not present the endothermic peak of both curcumin and phosphatidylcholine. The melting peak of curcumin and phosphatidylcholine were completely disappeared. Instead, it showed new melting peaks with lower endothermic effect of phosphatidylcholine (onset temperature $131.4244{ }^{\circ} \mathrm{C}$ and meilting peak $116.6517^{\circ} \mathrm{C}$ ). This proves that curcumin reacts with phosphatidylcholine to form the chemical bonds between the $\mathrm{OH}$ in phenol group of curcumin structure with phosphatidylcholine's polar head.

\section{${ }^{1} \mathrm{H}$ NMR spectroscopy}

The proton NMR spectrum of curcumin, phosphatidylcholine and phytosome curcumin was represented in Figure 7. In ${ }^{1} \mathrm{H}-\mathrm{NMR}$ of phytosome curcumin signals at $\delta 0.876,1.296$ and 2.764 ppm showed that the signals of protons of methyl, methylene group of aliphatic side chain and methylene protons linked to- $\mathrm{C}(=\mathrm{O})-\mathrm{C}$ group, respectively. They are characteristics of nonpolar portion of phosphatidylcholine molecule. The signal of protons at $\delta 5.334 \mathrm{ppm}$ is due to signals of second methylene group proton near $\mathrm{N}$ atom $(-\mathrm{CH} 2 \mathrm{CH} 2 \mathrm{~N})$ of choline and signals at $\delta 3.362 \mathrm{ppm}$ is due to protons of methyl group attached to $\mathrm{N}$-atom of choline which represented a signal broadening due to their involvement in phytosome curcumin (Sikarwar et al., 2008). The
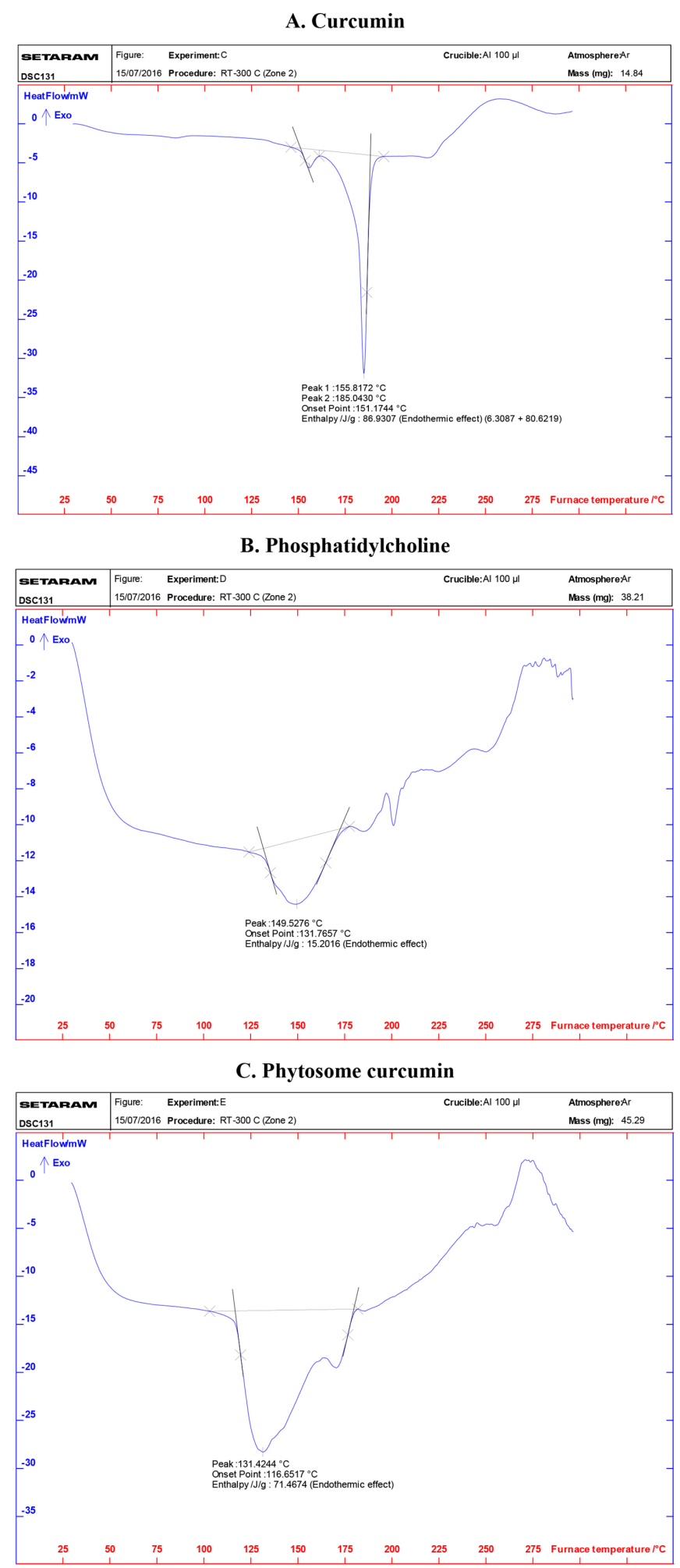

FIGURE 6 - Differential scanning calorimetry (DSC) thermograph of curcumin (A), phosphatidylcholine (B) and phytosome curcumin (C). 
protons signals at 5.779-5.983; 6.459-6.491; 6.926-6.942; 7.049-7.052; 7.112-7.132 and 7.572-7.604 [m, ArH] are due to aromatic ring of curcumin. These data suggested that phenyl group of curcumin was complexed with choline part of phosphatidylcholine.
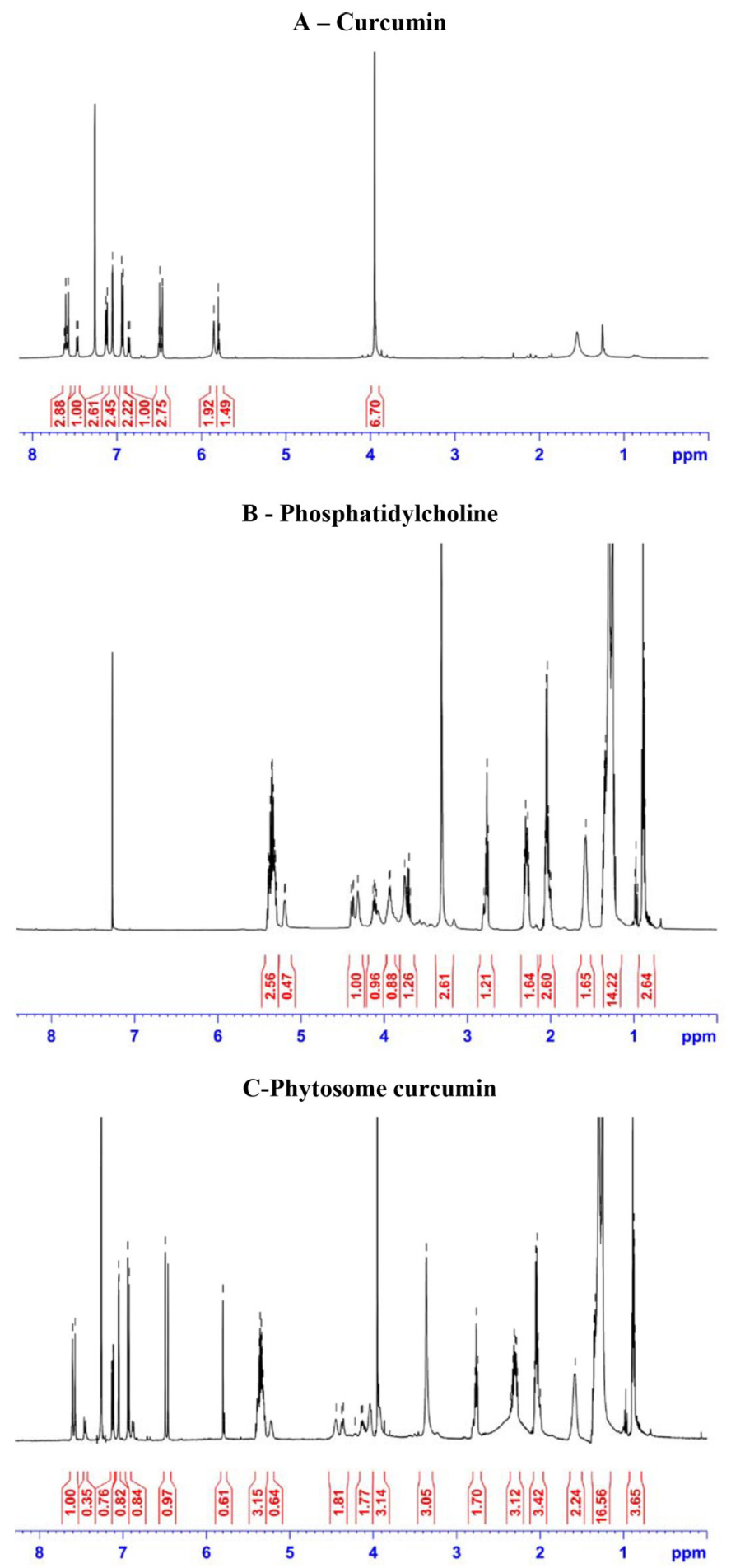

FIGURE 7 - Proton NMR Spectrum of Curcumin (A), Phosphatidylcholine (B) and Phytosome curcumin (C).

\section{Solubility studies}

Solubility of curcumin, phytosome and physical mixture of curcumin and phosphatidylcholine in water0 was shown in Table III.

Curcumin, a hydrophobic molecule, is practically insoluble in water, especially at $\mathrm{pH}$ 1.2. Therefore, curcumin has very low bioavailability; this is a barrier of using curcumin in clinical application. When $\mathrm{pH}$ was increased, curcumin's solubility tends to increase but still is very low. Solubility of curcumin in n-octanol is also very low. Therefore, bioavailability of curcumin by oral via or derma via is extremely low. Phytosome curcumin can significantly improve solubility of curcumin in solution at different $\mathrm{pH}$ and also in n-octanol. Thereby phytosome curcumin can increase the partition coefficient $\mathrm{O} / \mathrm{W}$, lead curcumin easily to diffuse into the cell membrane, easily transferred from the aqueous phase to the lipid phase, then increasing its bioavaibility.

\section{Biological activity}

Enzyme such as AST and ALT are main liver transaminases have been used for the assessment of liver damage (Howell et al., 2014).

Serum ALT and AST activities were significantly increased in PAR group as compared with control group (Table IV). When mice were treated with phytosome, the ALT and AST activities were significantly decreased as compared to the PAR group. These enzymes activities tended to decrease in Cur 200 group compared with PAR group.

\section{Lipid peroxidation}

The levels of lipid peroxidation product (MDA) from the liver tissues in the studied groups were shown in Table $\mathrm{V}$ and Figure 8. An increased in MDA level was observed significantly in the PAR group when compared with control group $(p<0.05)$. A decreased in MDA levels were observed significantly in group of Phyt 100 and Phyt $200(p<0.05)$. The level of MDA tended to decrease in Cur 200 group compared with PAR group.

\section{Antioxidant enzyme analysis}

We also determined the activities of several antioxidant enzymes including CAT, SOD and GPx in the liver tissue of control and experimental animals. The results were reported in Table V and Figures 9, 10 and 11. Mice in PAR group showed a significant lower in the activities of these antioxidants compared with control group $(\mathrm{p}<0.05)$. Mice in groups Phyt 100 and Phyt 200 exhibited significant increasing in the levels of CAT, 
TABLE III - Solubility of curcumin, phytosome and mixture of curcumin and phosphatidylcholine in different medium

\begin{tabular}{|c|c|c|c|c|c|}
\hline Sample & $\begin{array}{c}\text { Solubility } \\
\text { in water } \\
(\mu \mathrm{g} / \mathrm{mL})\end{array}$ & $\begin{array}{c}\text { Solubility in } \\
\text { solution } \\
\text { HCL } 0,1 \mathrm{~N} \\
(\mu \mathrm{g} / \mathrm{mL})\end{array}$ & $\begin{array}{c}\text { Solubility in } \\
\text { buffer solution } \\
\text { phosphate } \\
\text { pH 4,5 } \\
(\mu \mathrm{g} / \mathrm{mL}) \\
\end{array}$ & $\begin{array}{c}\text { Solubility in b } \\
\text { uffer solution } \\
\text { phosphate } \\
\text { pH } 6,8 \\
(\mu \mathrm{g} / \mathrm{mL}) \\
\end{array}$ & $\begin{array}{c}\text { Solubility in } \\
n \text {-octanol } \\
(\mathrm{mg} / \mathrm{mL})\end{array}$ \\
\hline Curcumin & $8,2 \pm 3,1$ & $3,1 \pm 2,3$ & $13,3 \pm 1,4$ & $21,7 \pm 1,4$ & $4,1 \pm 3,7$ \\
\hline $\begin{array}{l}\text { Mixture of curcumin and } \\
\text { phosphatidylcholine (ratio 1:1) }\end{array}$ & $17,7 \pm 2,4$ & $10,1 \pm 2,4$ & $19,4 \pm 2,8$ & $30,1 \pm 5,1$ & $8,4 \pm 1,6$ \\
\hline Phytosome curcumin (ratio 1:1) & $38,7 \pm 1,4$ & $20,7 \pm 3,5$ & $32,7 \pm 4,3$ & $60,1 \pm 1,1$ & $44,1 \pm 1,8$ \\
\hline
\end{tabular}

TABLE IV - Effect of phytosome curcumin on liver marker enzymes

\begin{tabular}{lccccc}
\hline Parameters & Control & PAR & Cur 200 & Phyt 100 & Phyt 200 \\
\hline AST (IU/L) & $38.24 \pm 4.23$ & $101.28 \pm 11.25^{*}$ & $81.28 \pm 12.27$ & $47.25 \pm 5.24^{\#}$ & $41.25 \pm 5.32^{\#}$ \\
ALT (IU/L) & $31.12 \pm 5.21$ & $97.67 \pm 11.84^{*}$ & $68.58 \pm 14.45$ & $42.15 \pm 6.38^{\#}$ & $37.17 \pm 3.25^{\#}$ \\
\hline
\end{tabular}

TABLE V - The effect of administration of phytosome curcumin on lipid peroxidation and antioxidant enzymes in mice liver tissue

\begin{tabular}{lccccc}
\hline Parameters & Control & PAR & Cur 200 & Phyt 100 & Phyt 200 \\
\hline MDA & $0.52 \pm 0.14$ & $1.89 \pm 0.15^{*}$ & $1.61 \pm 0.13$ & $1.42 \pm 0.12^{\#}$ & $1.28 \pm 0.11^{\#}$ \\
SOD & $0.573 \pm 0.09$ & $0.187 \pm 0.08^{*}$ & $0.210 \pm 0.07$ & $0.282 \pm 0.10^{\#}$ & $0.362 \pm 0.12^{\#}$ \\
CAT & $298.87 \pm 39.15$ & $89.8 \pm 13.19^{*}$ & $129.8 \pm 14.21$ & $165.15 \pm 21.12^{\#}$ & $196.12 \pm 23.15^{\#}$ \\
GPx & $25.35 \pm 3.27$ & $10.19 \pm 2.32^{*}$ & $11.23 \pm 3.18$ & $13.68 \pm 2.72$ & $17.86 \pm 4.54^{\#}$ \\
\hline
\end{tabular}

Value represents as mean \pm S.D. ${ }^{*} \mathrm{p}<0.05$, significant difference compared with control group, ${ }^{\sharp} \mathrm{p}<0.05$, significant difference compared with paracetamol group $(n=10)$.

SOD and GPx compared with PAR group $(\mathrm{p}<0.05)$. These enzymes activities tended to increase in Cur 200 group compared with PAR group.

\section{DISCUSSION}

Preparing new formulation for curcumin delivery is important because of many beneficial effect of curcumin. Curcumin has poor absorption because of its low solubility (Maiti et al., 2007). Phospholipids are now using in many application of drug delivery technology. The advantage of phospholipids is increasing solubilizing property of many natural products. In this study, we have developed successfully phytosome curcumin which can improve the bioavailability of curcumin. The physicochemical data showed that curcumin formed a complex with phosphatidylcholine by hydrogen bonds. We also showed that the phytosome has increased the solubility of curcumin in different medium.

Paracetamol have been used in many study for induce liver damage (Farghaly, Hussein 2010). Liver is the main organ in body, which metabolizes chemicals and drug. It has been well known that enzyme AST and ALT are markers of hepatocyte damage and the high level of AST and ALT is an important marker for liver injury (McGill, Jaeschke, 2013). In our study, paracetamol significant induced hepatic damage in mice by increasing the level of AST and ALT. Our data are agreed with Nithianantham et al. (2011) they have showed that parcetamol significant increased the ALT, AST, and bilirubin levels in mice.

Phytosome curcumin protects the mice from PARinduced acute liver injury in vivo. After administration of paracetamol, serum ALT and AST levels in mice were significantly greater than those in control group, and phytosome curcumin could reduce those levels. Our results indicate that phytosome curcumin protects hepatocytes in vivo from damage induced by paracetamol administration. Our data are in line with previous report that curcumin can protect damages in liver caused by paracetamol (Kheradpezhouh et al., 2010).

When reactive oxidative stress attack polyunsaturated 


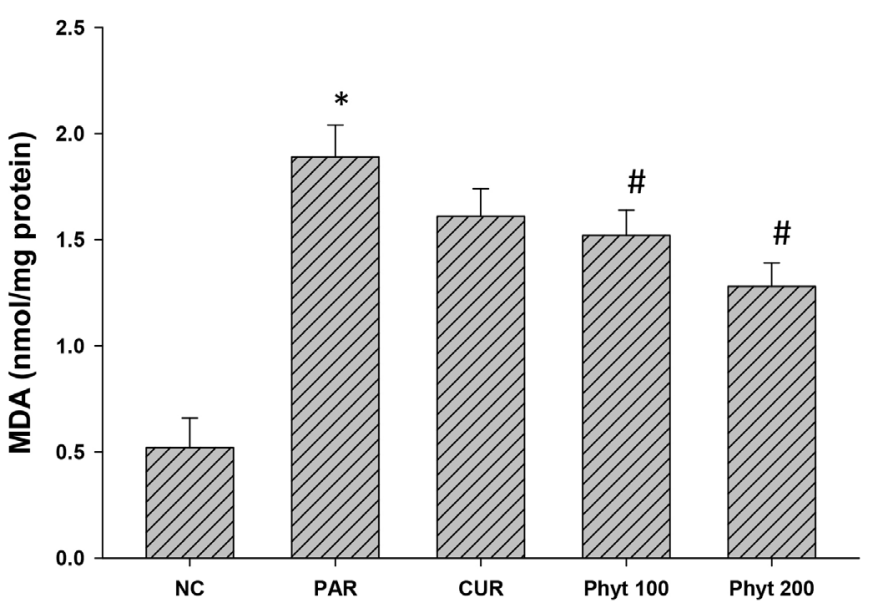

FIGURE 8 - Effect of phytosome curcumin on lipid peroxidation of control and treated animals in paracetamol-induced liver injury in mice. NC: Control group; PAR: mice received $1 \mathrm{~g} /$ $\mathrm{kg}$ b.w of Paracetamol; CUR: mice received $200 \mathrm{mg} / \mathrm{kg}$ b.w curcumin and $1 \mathrm{~g} / \mathrm{kg}$ b.w of Paracetamol; Phyt 100: mice received amount phytosome curcumin equivalent to curcumin $100 \mathrm{mg} / \mathrm{kg}$ b.w and $1 \mathrm{~g} / \mathrm{kg}$ b.w of Paracetamol; Phyt 200: mice received amount phytosome curcumin equivalent to curcumin $200 \mathrm{mg} / \mathrm{kg}$ b.w and $1 \mathrm{~g} / \mathrm{kg}$ b.w of Paracetamol; Value represents as mean \pm S.D. ${ }^{*} \mathrm{p}<0.05$, significant difference compared with control group, ${ }^{*} \mathrm{p}<0.05$, significant difference compared with paracetamol group $(n=10)$.

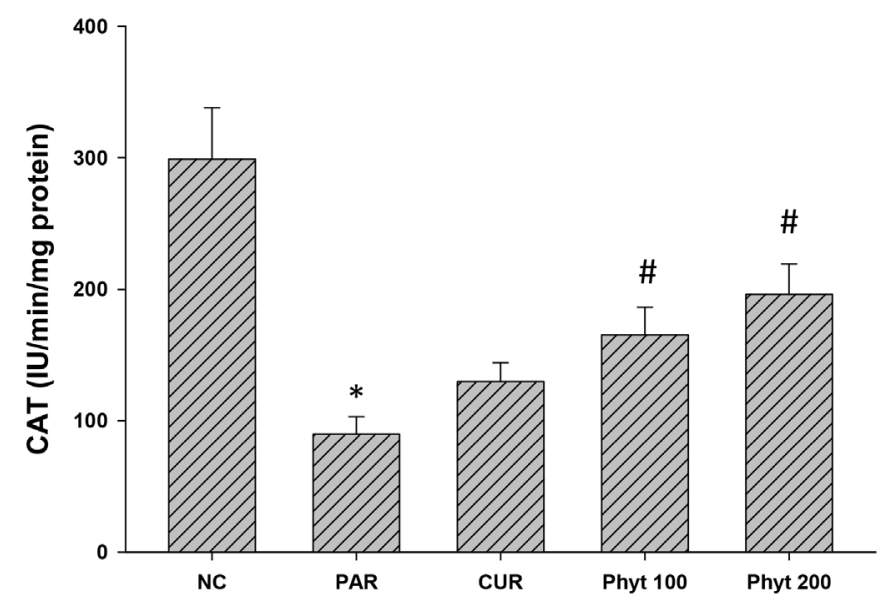

FIGURE 9 - Effect of phytosome curcumin on CAT activity of control and treated animals in paracetamol-induced liver injury in mice. Value represents as mean \pm S.D. ${ }^{*} p<0.05$, significant difference compared with control group, ${ }^{*} \mathrm{p}<0.05$, significant difference compared with paracetamol group $(n=10)$.

fatty acids and disrupt the cell membrane. It leads to oxidative lipid and forms MDA, a product of lipid peroxidation. Increasing production of liver MDA observed in our experiments by PAR are in agreement with previous study which reported that PAR increased extracellular

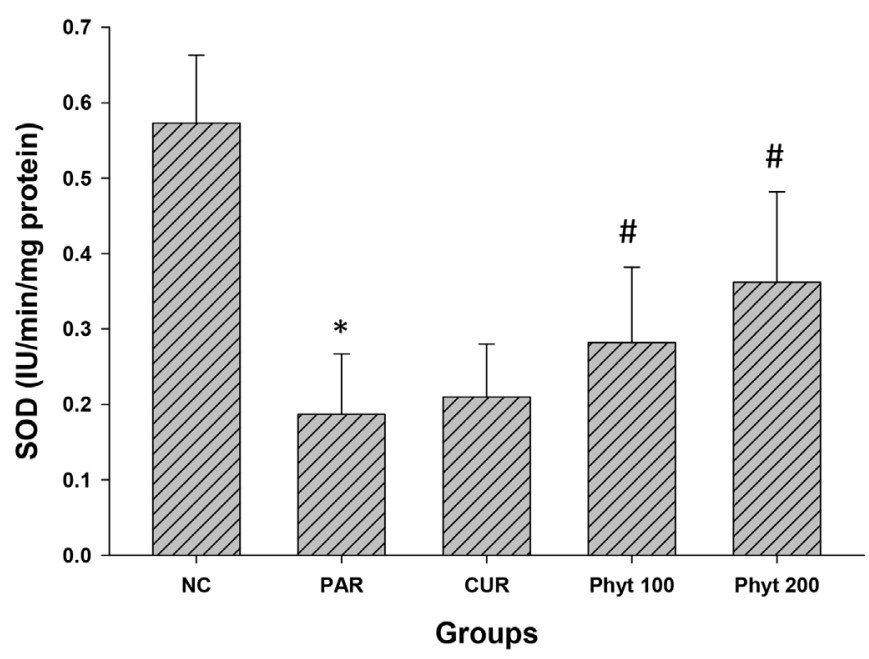

FIGURE 10 - Effect of phytosome curcumin on SOD activity of control and treated animals in paracetamol-induced liver injury in mice. Value represents as mean \pm S.D. ${ }^{*} p<0.05$, significant difference compared with control group, ${ }^{*} \mathrm{p}<0.05$, significant difference compared with paracetamol group $(n=10)$.

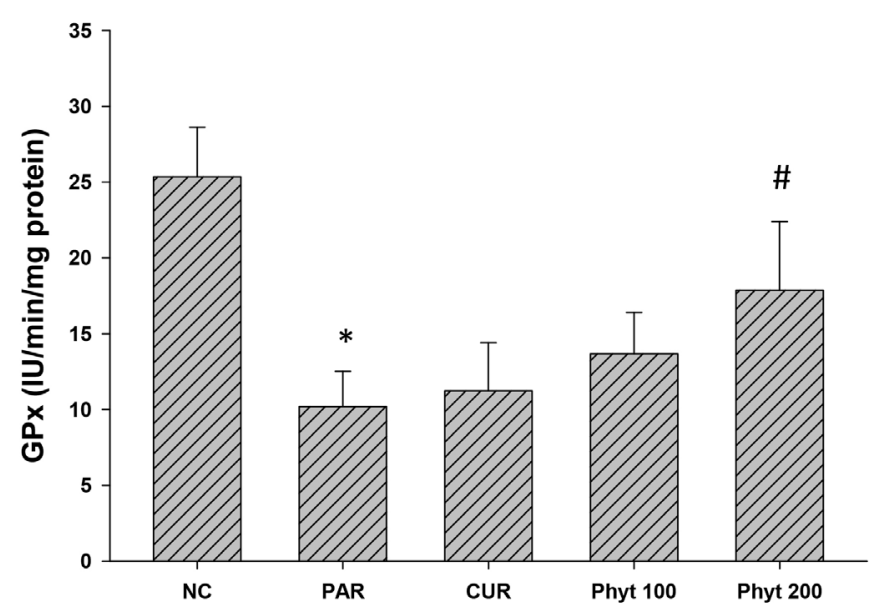

FIGURE 11 - Effect of phytosome curcumin on GPx activity of control and treated animals in paracetamol-induced liver injury in mice. Value represents as mean \pm S.D. ${ }^{*} p<0.05$, significant difference compared with control group, ${ }^{\#} \mathrm{p}<0.05$, significant difference compared with paracetamol group $(n=10)$.

MDA level (Boonruamkaew, Chonpathompikunlert et al., 2016). In addition, we have shown phytosome curcumin may diminish the level of MDA in liver tissues. Our data are in line with study of Hatem et al. which showed that hepatic lipid peroxidation level was suppressed by administration of curcumin to paracetamol-treated rats (Farghaly, Hussein 2010).

The organism can develop a mechanism, such as the antioxidant system SOD, CAT and GPx to decrease the damage cause by ROS. SOD, CAT and GPx are 
endogenous enzymatic against ROS. SOD is antioxidant enzyme that converts superoxide anion $\mathrm{O}_{2}{ }^{-}$to $\mathrm{H}_{2} \mathrm{O}_{2}$. CAT converts $\mathrm{H}_{2} \mathrm{O}_{2}$ to water and $\mathrm{O}_{2}$. GPx catalyzes the reduction of $\mathrm{H}_{2} \mathrm{O}_{2}$ and other peroxides by coupling reduced glutathione (Madrigal-Santillan et al., 2014; Thanh et al., 2015). Our data have showed the activities of these enzymes in PAR group were declined. Interestingly when mice were treated with phytosome curcumin, these enzymes can be reversed significantly.

The hepatoprotective effect of phytosome was significantly higher than curcumin free at the same dose. Free curcumin at the dose of $200 \mathrm{mg} / \mathrm{kg}$ only slightly reduced the damage conditions in mice induced by paracetamol. The phytosome at dose equivalent to 100 $\mathrm{mg} / \mathrm{kg}$ of curcumin showed higher restored the damage of mice liver compared with curcumin free at double dose $(200 \mathrm{mg} / \mathrm{kg})$. The increasing hepatoprotective efficacy of phytosome curcumin may be explained by increasing bioavailability of the curcumin.

In summary, this study demonstrates that phytosome curcumin had a strong protective effect against paracetamol-induced acute hepatic damage in mice. The hepatoprotective effect of phytosome curcumin may be explained by increasing levels of antioxidant enzymes and decreasing the lipid peroxidation and liver enzyme on paracetamol-induced damage in mice.

\section{CONFLICTS OF INTERESTS}

The authors declare no conflict of interest.

\section{ACKNOWLEDGEMENTS}

The authors would like to thank the financial support of project (Grant number QG.16.25) from the Vietnam National University Ha Noi, Vietnam.

\section{REFERENCES}

ANAND, P.; THOMAS, S.G.; KUNNUMAKKARA, A.B.; SUNDARAM, C.; HARIKUMAR, K.B.; SUNG, B.; THARAKAN, S.T.; MISRA, K.; PRIYADARSINI, I.K.; RAJASEKHARAN, K.N. Biological activities of curcumin and its analogues (Congeners) made by man and Mother Nature. Biochem. Pharmacol., v.76, n.11, p.1590-1611, 2008.

BOONRUAMKAEW, P.; CHONPATHOMPIKUNLERT, P.; NAGASAKI, Y. Redox nanoparticle therapeutics for acetaminophen-induced hepatotoxicity in mice. Oxid. Med. Cell. Longev., v.2016, p.1-10, 2016.
CUOMO, J.; APPENDINO, G.; DERN, A.S.; SCHNEIDER, E.; MCKINNON, T.P.; BROWN, M.J.; TOGNI, S.; DIXON, B.M. Comparative absorption of a standardized curcuminoid mixture and its lecithin formulation. J. Nat. Prod., v.74, n.4, p.664-669, 2011.

ELOY, J.O.; SOUZA, M.C.; PETRILLI, R.; BARCELLOS, J.P.A.; LEE, R.J.; MARCHETTI, J.M. Liposomes as carriers of hydrophilic small molecule drugs: Strategies to enhance encapsulation and delivery. Colloids Surf., B, v.123, p.345-363, 2014.

FARGHALY, H.S.; HUSSEIN, M.A. Protective effect of curcumin against paracetamol-induced liver damage. Aust. J. Basic Appl. Sci., v.4, n.9, p.4266-4274, 2010.

GUPTA, S.C.; PATCHVA, S.; AGGARWAL, B.B. Therapeutic roles of curcumin: lessons learned from clinical trials. AAPS J., v.15, n.1, p.195-218, 2013.

HINSON, J.A.; ROBERTS, D.W.; JAMES, L.P. Mechanisms of acetaminophen-induced liver necrosis. Handb. Exp. Pharmacol., v.2010, n.196, p.369-405, 2010.

HOWELL, B.; SILER, S.; SHODA, L.; YANG, Y.; WOODHEAD, J.; WATKINS, P.B. A mechanistic model of drug-induced liver injury aids the interpretation of elevated liver transaminase levels in a phase I clinical trial. CPT: Pharmacometrics Syst. Pharmacol., v.3, n.2, p.1-8, 2014.

JAESCHKE, H.; RAMACHANDRAN, A. Reactive oxygen species in the normal and acutely injured liver. J. Hepatol., v.55, n.1, p.227-228, 2011.

KHERADPEZHOUH, E.; PANJEHSHAHIN, M.-R.; MIRI, R.; JAVIDNIA, K.; NOORAFSHAN, A.; MONABATI, A.; DEHPOUR, A.-R. Curcumin protects rats against acetaminophen-induced hepatorenal damages and shows synergistic activity with $\mathrm{N}$-acetyl cysteine. Eur. J. Pharmacol., v.628, n.1, p.274-281, 2010.

KIM, T.D.; THANH, H.N.; THUY, D.N.; DUC, L.V.; THI, T.V.; MANH, H.V.; BOONSIRI, P.; THANH, T.B. Anticancer effects of saponin and saponin-phospholipid complex of Panax notoginseng grown in Vietnam. Asian Pac. J. Trop. Biomed., v.6, n.9, p.795-800, 2016. 
MADRIGAL-SANTILLAN, E; MADRIGAL-BUJAIDAR, E.; ALVAREZ-GONZALEZ, I.; SUMAYA-MARTINEZ, M.T.; GUTIERREZ-SALINAS, J.; BAUTISTA, M.; MORALES-GONZALEZ, A.; GARCIA-LUNA, M.; GONZALEZ-RUBIO, Y.; AGUILAR-FAISAL, J.L.; MORALES-GONZALEZ, J.A. Review of natural products with hepatoprotective effects. World J. Gastroenterol., v.20, n.40, p.14787-14804, 2014.

MAITI, K.; MUKHERJEE, K.; GANTAIT, A.; SAHA, B.P.; MUKHERJEE, P.K. Curcumin-phospholipid complex: Preparation, therapeutic evaluation and pharmacokinetic study in rats. Int. J. Pharm., v.330, n.1/2, p.155-163, 2007.

MARCZYLO, T.H.; VERSCHOYLE, R.D.; COOKE, D.N.; MORAZZONI, P.; STEWARD, W.P.; GESCHER, A.J. Comparison of systemic availability of curcumin with that of curcumin formulated with phosphatidylcholine. Cancer Chemother. Pharmacol., v.60, n.2, p.171-177, 2007.

MCGILL, M.R.; JAESCHKE, H. Metabolism and disposition of acetaminophen: recent advances in relation to hepatotoxicity and diagnosis. Pharm. Res., v.30, n.9, p.2174-2187, 2013.

M C G I L L, M.R .; W I L L I A M S , C . D .; X I E, Y. ; RAMACHANDRAN, A.; JAESCHKE, H. Acetaminopheninduced liver injury in rats and mice: comparison of protein adducts, mitochondrial dysfunction, and oxidative stress in the mechanism of toxicity. Toxicol. Appl. Pharmacol., v.264, n.3, p.387-394, 2012.

MOREIRA, J.N.; GASPAR, R.; ALLEN, T.M. Targeting stealth liposomes in a murine model of human small cell lung cancer. Biochim. Biophys. Acta, v.1515, n.2, p.167-176, 2001.

NITHIANANTHAM, K.; SHYAMALA, M.; CHEN, Y.; LATHA, L.Y.; JOTHY, S.L.; SASIDHARAN, S. Hepatoprotective potential of clitoria ternatea leaf extract against paracetamol induced damage in mice. Molecules, v.16, n.12, p.10134, 2011.

NOBLE, J.E.; BAILEY, M.J. Quantitation of protein. Methods Enzymol., v.463, p.73-95, 2009.
PEREIRA-LACHATAIGNERAIS, J.; PONS, R.; PANIZZA, P.; COURBIN, L.; ROUCH, J.; LOPEZ, O. Study and formation of vesicle systems with low polydispersity index by ultrasound method. Chem. Phys. Lipids, v.140, n.1/2, p.88-97, 2006.

PHAM, T.M.H.; NGUYEN, L.T.; NGUYEN, V.L.; LE, P.L.; HO, A.S.; NGUYEN, T.H.; BUI, T.T. Developing and evaluating in vitro effect of pegylated liposomal doxorubicin on human cancer cells. J. Chem. Pharm. Bull., v.7, n.3, p.2239-2243, 2015.

PRASAD, S.; TYAGI, A.K.; AGGARWAL, B.B. Recent developments in delivery, bioavailability, absorption and metabolism of curcumin: the golden pigment from golden spice. Cancer Res. Treat., v.46, n.1, p.2-18, 2014.

SHYAM, K.R.; KUMAR, G.M. Prepration, charactaerization and antioxidant activities of gallic acid-phospholipids complex. Int. J. Res. Pharm. Sci., v.2, n.1, p.138-148, 2012.

SIKARWAR, M.S.; SHARMA, S.; JAIN, A.K.; PARIAL, S.D. Preparation, characterization and evaluation of Marsupsinphospholipid complex. AAPS PharmSciTech, v.9, n.1, p.129-137, 2008.

SIVIERO, A.; GALLO, E.; MAGGINI, V.; GORI, L.; MUGELLI, A.; FIRENZUOLI, F.; VANNACCI, A. Curcumin, a golden spice with a low bioavailability. $J$. Herbal Med., v.5, n.2, p.57-70, 2015.

THANH, T.B.; THANH, H.N.; MINH, H.P.T.; LE-THI-THU, H.; LY, H.D.T.; DUC, L.V. Protective effect of Tetracera scandens L. leaf extract against CCl4-induced acute liver injury in rats. Asian Pacific J. Trop. Biomed., v.5, n.3, p.221-227, 2015.

THANH, H.N.; MINH, H.P.T.; DUC, L.V.; THANH, T.B. Protective effect of coenzyme Q10 on methamphetamineinduced neurotoxicity in the mouse brain. Trends Med. Res., v.11, n.1, p.1-10, 2016.

Received for publication on $16^{\text {th }}$ July 2016 Accepted for publication on $01^{\text {st }}$ November 2016 